\title{
Calving sub-season and reproductive efficiency of beef cows
}

\author{
Cristiane Reinher ${ }^{1}$, Júlio Otávio Jardim Barcellos ${ }^{2,3}{ }^{, V}$ anessa Peripolli ${ }^{1}$, Ênio Rosa Prates ${ }^{2}$, \\ Maria Eugênia Andrighetto Canozzi ${ }^{1}$
}

\begin{abstract}
1 Programa de Pós-Graduação em Zootecnia, Universidade Federal do Rio Grande do Sul (UFRGS), Porto Alegre, RS, Brasil. 2 Departamento de Zootecnia, UFRGS, Porto Alegre, RS, Brasil. Av. Bento Gonçalves, 7712, CEP: 91540-000, Porto Alegre, RS.

${ }^{3}$ Pesquisador II do CNPq.
\end{abstract}

ABSTRACT - It was evaluated in this work the effect of calving sub-season on the pregnancy rate of 7,726 multiparous Hereford beef cows grazing on natural pastures in southern Brazil, from 1994 to 2007. Calving sub-season periods were divided in 20-day intervals from August $12^{\text {th }}$ to $31^{\text {st }}$, from September $1^{\text {st }}$ to $20^{\text {th }}$, from September $21^{\text {st }}$ to October $10^{\text {th }}$, from October $11^{\text {th }}$ to $31^{\text {st }}$, from November $1^{\text {st }}$ to $20^{\text {th }}$. Calving in each sub-season and pregnancy rate (PR) were analyzed by the Chi-square test. Overall means of each sub-season were $92.7 \%$ (from August $12^{\text {th }}$ to $31^{\text {st }}$ ), 90.6\% (from September $1^{\text {st }}$ to $20^{\text {th }}$ ), $82.1 \%$ (from September $21^{\text {st }}$ to October $10^{\text {th }}$ ), $77.7 \%$ (from October $11^{\text {th }}$ to $31^{\text {st }}$ ), and $70.6 \%$ (from November $1^{\text {st }}$ to $\left.20^{\text {th }}\right)$. Calving sub-season significantly influenced pregnancy rate. Cows which calved in the initial sub-season showed higher pregnancy rates than cows which calved from the fourth calving sub-season. However this difference did not occur in 1999 and in 2007 since calving rates did not statistically differ among the five sub-seasons. In 1998 and 2004, calving rates were lower and the effects of calving sub-season on pregnancy rates were higher, possibly due to climate variations. In general, pregnancy rate decreases as calving occurs later in the year, particularly in years when the weather adversely affects pasture growth.

Key Words: calving date, cow-calf, multiparous, pregnancy rate

\section{Subépoca de parição e eficiência reprodutiva de vacas de corte}

RESUMO - Avaliou-se o efeito da subépoca de parição sobre a taxa de prenhez de 7.726 vacas de corte multíparas Hereford mantidas em campo natural no Sul do Brasil, entre os anos de 1994 e 2007. As subépocas foram divididas em intervalos de 20 dias: de 12 a 31 de agosto; de 1 a 20 de setembro; 21 de setembro a 10 de outubro; 11 a 31 de outubro; e 1 a 20 de novembro. Foram analisados os partos ocorridos na subépoca de parição e a taxa de prenhez (PR) pelo qui-quadrado. As médias gerais de cada subépoca foram 92.7\% (12 a 31 de agosto), 90.6\% (1 a 20 de setembro), 82.1\% (21 de setembro a 10 de outubro), 77.7\% (11 a 31 de outubro) e 70.6\% (1 a 20 de novembro), respectivamente. Houve efeito significativo da subépoca de partos sobre a taxa de prenhez. As vacas que pariram nas primeiras subépocas apresentaram maiores taxas de prenhez em relação às que pariram a partir da quarta subépoca de parição. No entanto, essa diferença não se manteve nos anos de 1999 e 2007, uma vez que as taxas de prenhez não diferiram estatisticamente nas cinco subépocas. Nos anos de 1998 e 2004, as taxas de prenhez foram menores e os efeitos da subépoca de parição sobre a taxa de prenhez foram de maior magnitude, possivelmente em decorrência de variações climáticas. De modo geral, as taxas de prenhez diminuem com o avanço da data de parto dentro do ano, sobretudo nos anos de eventos climáticos desfavoráveis ao crescimento do pasto.

Palavras-chave: estação de parição, gado de cria, multíparas, taxa de prenhez

\section{Introduction}

Reproductive efficiency is the most important component in beef production systems, and understanding the variables that affect it is essential for taking management decisions. The main factors that influence reproductive indexes are pre- and post-calving nutritional levels, body weight and body condition score at calving, calving season, milk production, breed, and age at calving (Osoro \& Wright, 1992).

In beef production, breeding has increasingly lost space to other production stages due to its low biological efficiency and profitability and it is usually left to the poorest pastures that frequently do not supply the nutritional requirements of breeding cows. Therefore, applying proper nutritional management 
before and after calving, adjusting stocking rates, good body condition score at calving, and the correct choice of breeding seasons, and consequently, calving seasons are critical to obtain high reproductive indexes (Barcellos, 1999).

Defining a breeding season is beneficial for the breeding herd, as it allows matching the nutritional requirements of cows to nutrient availability according to the season of the year. When breeding multiparous cows, a breeding season not longer than 90 days is recommended in order to obtain higher concentration of calving and calving intervals shorter than 365 days (Lobato, 1985; Wiltbank, 1970). In a study carried out by Reinher et al. (2006), it was observed that multiparous cows, despite showing a more disperse calving season as compared to an ideal theoretical model ( $60 \%$ calving in the first 21 days of the calving season), presented high pregnancy rates.

In pasture-based beef production systems, the effect of calving dates during the spring on calving-conception interval is increasingly evident. Late-calving cows present lower calving-estrus intervals, but lower estrus frequency during the breeding season, reducing their opportunities to conceive (Pimentel \& Pimentel, 1983). Therefore, it is important to understand the effect of calving season on pregnancy rates in order to determine management strategies in breeding herds.

This study aimed at evaluating the effect of calving sub-season on the reproductive performance of beef cows kept on natural pastures.

\section{Material and Methods}

Data were collected from a commercial farm located in the region of Campanha, state of Rio Grande do Sul, Brazil. Records from 1994 to 2007 on 7,726 Hereford multiparous cows were analyzed.

The calving season was divided in 20-day intervals into five sub-seasons: from August $12^{\text {th }}$ to the $31^{\text {st }}$, from September $1^{\text {st }}$ to the $20^{\text {th }}$; from September $21^{\text {st }}$ to the October $10^{\text {th }}$, from October $11^{\text {th }}$ to the $31^{\text {st }}$, and from November $1^{\text {st }}$ to the $20^{\text {th }}$. Each sub-season included the cows that calved during that period. The cow groups corresponding to each sub-season were submitted to the same nutritional and health management, at a stocking rate of $300 \mathrm{~kg} / \mathrm{ha}$, under rotational grazing system in order to avoid the effect from paddocks. In addition, the number of second-calf heifers was similar within each sub-season, as similar replacement rates and culling strategy were used to maintain the same herd structure throughout the analyzed years.
According to Köppen's classification, the local climate is mesothermal, subtropical, class $\mathrm{Cfa}$, with rainfall regularly distributed during the year and occasional dry periods from December to January. Average temperatures of 15.6, 17.8, 21.3, 23.1, and $25.7^{\circ} \mathrm{C}$, and mean rainfall values of 93.3, 92.4, $79.0,101.5$, and $80 \mathrm{~mm}$ were recorded during the subseasons of August $12^{\text {th }}$ to the $31^{\text {st }}$, September $1^{\text {st }}$ to the $20^{\text {th }}$; September $21^{\text {st }}$ to October $10^{\text {th }}$, October $11^{\text {th }}$ to $31^{\text {st }}$, and November $1^{\text {st }}$ to the $20^{\text {th }}$, respectively.

The predominant vegetation consisted of Bahia grass (Paspalum notatum), dallis or water grass (Paspalum dilatatum) and blanket grass (Axonopus compressus). The main legumes were Desmodium pratensis and Tripholium polimorfum. Forage during the pre-calving period ranged from 700 to 1,200 kg/hectare dry matter (DM) and from 1,000 to $1,600 \mathrm{~kg} / \mathrm{ha} \mathrm{DM}$ post-calving. Breeding season lasted for 90 days, from November $15^{\text {th }}$ to February $15^{\text {th }}$, calvings occurred from August $12^{\text {th }}$ to November $20^{\text {th }}$, and a $4 \%$ bull ratio was used in the breeding herd.

Pregnancy rate (PR), resulting from the breeding season after calving sub-seasons, was determined by pregnancy diagnosis at the end of the breeding season, and analyzed by Chi-Square method using SAS statistical package (SAS, 1990). Average Julian calving date within each sub-season was calculated based on the average between the first and the last day of each sub-season, and its effects on pregnancy rate resulting from the next breeding season were submitted to analysis of regression, adjusted for the 14-year average and for the years with the highest (1999) and the lowest (1998) pregnancy rates.

\section{Results and Discussion}

Statistical analyses showed the influence $(\mathrm{P}<0.05)$ of calving sub-season and year on pregnancy rate. Average pregnancy rates in each sub-season during the 14 studied years, were: $92.7 \%$ (August 12-31), 90.6\% (September 1-20), 82.1\% (September 21 -October 10), 77.7\% (October 11-31), and 70.6\% (November 1-20) (Table 1).

These results show that the later calvings started, the lower the pregnancy rates. These values are consistent with the findings of Osoro \& Wright (1992) and Barcellos et al. (1997). According to Silva (1989) and Pimentel \& Pimentel (1983), within a defined calving season, cows that calve in the first sub-season present higher calving-first estrus; however, they present a higher number of estrus during the breeding season, and therefore, have higher chances to conceive.

Cows that calve later in the season, from October $11^{\text {th }}$ to the $31^{\text {st }}$ and from November $1^{\text {st }}$ to the $20^{\text {th }}$, presented 
Table 1 - Pregnancy rate of multiparous cows during the studied sub-seasons

\begin{tabular}{|c|c|c|c|c|c|c|c|}
\hline \multirow[b]{3}{*}{ Year } & & \multicolumn{5}{|c|}{ Sub-season } & \multirow[b]{3}{*}{ Average, \% } \\
\hline & & \multicolumn{5}{|c|}{ September } & \\
\hline & Cows & August 12-31 & September 1-20 & 21-October 10 & October 11-31 & November $1-20$ & \\
\hline 1994 & 400 & $88.7 a$ & $88.7 a$ & $78.8 \mathrm{~b}$ & $78.8 \mathrm{~b}$ & $78.8 \mathrm{~b}$ & 83.6AG \\
\hline 1995 & 485 & $94.0 \mathrm{a}$ & $94.0 \mathrm{a}$ & $95.3 \mathrm{a}$ & $85.8 b$ & $85.8 b$ & $91.9 \mathrm{BF}$ \\
\hline 1996 & 606 & $95.4 \mathrm{a}$ & $92.1 \mathrm{a}$ & $84.9 b$ & $80.6 b$ & $68.7 d$ & $85.8 \mathrm{~A}$ \\
\hline 1997 & 555 & $89.5 a$ & $89.5 a$ & $90.6 a$ & $82.2 b$ & $78.0 \mathrm{~b}$ & $86.1 \mathrm{AC}$ \\
\hline 1998 & 509 & $68.5 a$ & $69.5 a$ & $50.0 \mathrm{~b}$ & $37.6 \mathrm{c}$ & $37.6 c$ & $53.6 \mathrm{D}$ \\
\hline 1999 & 320 & $69.5 a$ & $97.6 a$ & $96.0 \mathrm{a}$ & $94.6 \mathrm{a}$ & $94.6 \mathrm{a}$ & $95.9 \mathrm{E}$ \\
\hline 2000 & 512 & $97.5 a$ & $99.3 a$ & $93.4 \mathrm{a}$ & $93.4 b$ & $77.2 \mathrm{c}$ & 93.9BE \\
\hline 2001 & 590 & $99.0 \mathrm{a}$ & $92.4 \mathrm{a}$ & $89.1 \mathrm{ab}$ & $84.8 c$ & $75.6 \mathrm{~d}$ & $89.6 \mathrm{CF}$ \\
\hline 2002 & 737 & $96.5 a$ & $83.3 a$ & $77.0 \mathrm{a}$ & $67.5 c$ & $63.6 c$ & $80.6 \mathrm{G}$ \\
\hline 2003 & 640 & $91.4 \mathrm{a}$ & $92.8 \mathrm{a}$ & $88.0 \mathrm{a}$ & $75.0 \mathrm{~b}$ & $69.8 b$ & $84.2 \mathrm{AG}$ \\
\hline 2004 & 660 & $91.7 \mathrm{a}$ & $91.7 \mathrm{a}$ & $81.0 \mathrm{~b}$ & $63.8 c$ & $40.0 \mathrm{~d}$ & $68.0 \mathrm{H}$ \\
\hline 2005 & 565 & $94.5 a$ & $93.2 \mathrm{a}$ & $86.6 b$ & $75.4 c$ & $72.8 c$ & 84.0AG \\
\hline 2006 & 565 & $94.6 a$ & $93.3 a$ & $84.7 b$ & $75.4 c$ & $72.8 c$ & $84.0 \mathrm{AG}$ \\
\hline 2007 & 582 & $91.6 a$ & 94.1 & $88.0 \mathrm{a}$ & 89.8a & $87.1 \mathrm{a}$ & $90.0 \mathrm{~F}$ \\
\hline Means & & $92.7 \mathrm{a}$ & $90.6 b$ & $82.1 \mathrm{c}$ & $77.7 \mathrm{C}$ & $70.6 \mathrm{~d}$ & 83.6 \\
\hline
\end{tabular}

* Means in the same row followed by different small letter are different $(\mathrm{P}<0.05)$ by Chi-Square test.

** Means in the same column followed by different capital letter are different $(\mathrm{P}<0.05)$ by Chi-Square test.

lower pregnancy rates usually because they did not have enough time to leave post-calving anestrus and to have a sufficient number of estrus during the breeding season. Vieira et al. (2005), working with five 20-day calving subseasons, found that pregnancy rates were higher than $90 \%$ when calvings occurred during the first sub-season (from August $12^{\text {th }}$ to September $1^{\text {st }}$ ) and $79.9 \%$ for calving occurring during the last sub-season (from October $31^{\text {st }}$ to November $20^{\text {th }}$ ). This demonstrates that calving date and season strongly influence reproductive performance. In addition, these effects may be stronger, depending on cow feeding levels and body condition score at calving (Hansen \& Hauser, 1982). Moreover, cows that conceive late in the next breeding season tend to present the same or a worse trend, and may calve late during their entire reproductive life or present reproductive failure (Wilbank, 1970). The results of the present study demonstrate that, according to calving sub-season, the reproductive performance of the cows may be different during the breeding season, and consequently, corrective management measures need to be applied.

The lowest pregnancy rates $(\mathrm{P}<0.05)$ occurred in 1998 and 2004 (53.6 and 68.0\%, respectively). In 1998, the reproductive index was low in all five sub-seasons, and in 2004, this happened only during the last two sub-seasons. These results may be explained by the adverse weather conditions experienced in 1998 and 2004. In 1998, rainfall during the last three calving sub-seasons (from September $21^{\text {st }}$ to October $10^{\text {th }}=46 \mathrm{~mm}$; from October $11^{\text {th }}$ to the $31^{\text {st }}$ $=24 \mathrm{~mm}$; from November $1^{\text {st }}$ to the $20^{\text {th }}=30 \mathrm{~mm}$ ) was much lower than the recorded average in that region. As the systems depend essentially on forage growth, which depends on rainfall rates, forage availability was markedly reduced. On the other hand, in 2004, the rainy period, which in turn usually occurs by the end of winter and it is responsible for the first growth cycle of spring pastures, was delayed. Also, during the subsequent breeding season (2004/2005), a drought (84 mm rainfall) was recorded from November to February, negatively influencing the pregnancy rates of the cows which calved during the subseasons of October $11^{\text {th }}$ to $31^{\text {st }}$ and November $1^{\text {st }}$ to the $20^{\text {th }}$. The estrus of cows that calve during this period is highly dependent on nutrient availability during the summer. In the present study, it was observed that drought reduce pasture quality and extended the period of anestrus, as the interval between calving and the end of the breeding season was shorter for the cow that calved during these last subseasons as compared to those calving in the sub-seasons from August $12^{\text {th }}$ to the $31^{\text {st }}$, September $1^{\text {st }}$ to the $20^{\text {th }}$, and September $21^{\text {st }}$ to October $10^{\text {th }}$.

According to Morris et al. (1978), climate interacts with nutrient availability. Therefore, during the years when the climate restricts forage growth, although the cows calve during the first sub-season, it is difficult to obtain good reproductive performance, as the low dry matter availability limits the weight gain required to allow cows to recover their body condition and ovary cyclicity before the end of the breeding season. During such years, if moderate pregnancy rates are obtained, these are probably due to the fact that there are cows better adapted to nutritional deficiency 
conditions, and consequently are able to face this period more efficiently, and to conceive again (Grecellé et al., 2006).

The results of the present experiment showed that pregnancy rates in 1996, 2000, 2004, 2005, and 2006 were similar until the second calving sub-season, and they decreased in the last three sub-seasons, except for 2001 and 2002. During those years, pregnancy rates were already statistically different in the second sub-season: from August $12^{\text {th }}$ to the $31^{\text {st }}$ (99.0 and 96.5\%), and from September $1^{\text {st }}$ to the $20^{\text {th }}$ (92.4 and 83.3\%), respectively. However, these indexes are not considered satisfactory. In 1995, 1997, and 2003, pregnancy rates started to decrease in the fourth subseason (from October $10^{\text {th }}$ to November $31^{\text {st }}$ ). On the other hand, in 1999 and in 2007, pregnancy rates were similar during all five calving sub-seasons. In all studied years, pregnancy rates were higher than $80 \%$ until the second subseason, except for 1998, when they presented low pregnancy rates in all five sub-seasons: from August $12^{\text {th }}$ to the $31^{\text {st }}$ (69.5\%), from September $1^{\text {st }}$ to the $20^{\text {th }}(69.5 \%)$, from September $21^{\text {st }}$ to October $10^{\text {th }}(50.0 \%)$, from October $11^{\text {th }}$ to the $31^{\text {st }}(37.6 \%)$, and from November $1^{\text {st }}$ to the $20^{\text {th }}$ (37.6\%).

The average pregnancy rates of each sub-season over the studied years were submitted to analysis of regression to evaluate the effects of calving using Julian date as reference. The line representing year average and year with the lowest pregnancy rate decreases as calving date increases, i.e., the later the cows calve, the lower their chances of conceiving again. However, the slope was steeper $(\mathrm{P}<0.05)$ in the year with the lowest pregnancy rate (Figure 1).

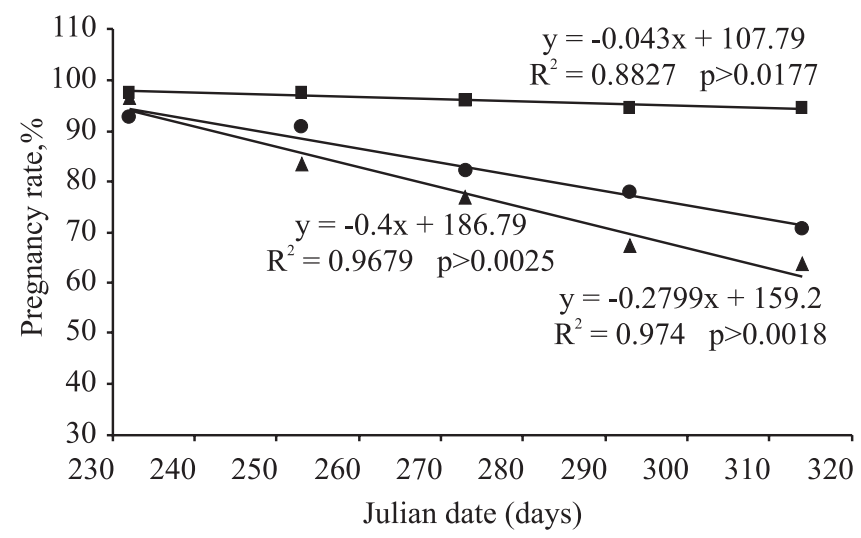

- General mean

- Year of the highest pregnancy rate

$\Delta$ Year of the lowest pregnancy rate

Figure 1 - Pregnancy rate of multiparous cows according to calving date and years with the highest (1999) or the lowest (1998) pregnancy rates.
These results are consistent with the findings by Grecellé et al. (2006), who observed in a herd submitted to feed restriction and 43.25 pregnancy rate, lower conception rates as calving date increased. However, in the present study, pregnancy rate was high and similar $(\mathrm{P}>0.05)$ among all five sub-season. This suggests that in both situations where pregnancy rate decreased as Julian date increased, the effect of calving sub-season was more evident, and may be stronger when there is negative influence from some variables, such as low forage availability, nutritional deficit, high milk production, and negative effects of rainfall.

Increasing Julian date in 10 days would reduce pregnancy rate by $0.43 \%, 2.80 \%$, and $4.0 \%$ in the year with the highest pregnancy rate, in the average of years, and in the year with the lowest pregnancy rate, respectively. The results obtained in the year with lowest pregnancy rate (53.62\%) are similar to those obtained by Pimentel \& Pimentel (1983), who showed that beef cows with $42 \%$ pregnancy rate presented a $5.1 \%$ decline in that rate for every ten additional days in calving date.

The results of the present study showed that in beefcattle breeding production systems based on natural pastures, whose growth depends on rainfall and temperature, the establishment of breeding season and duration, and consequently, calving season need to be balanced to achieve efficiency. Accordingly, it is essential to provide adequate conditions to the breeding cows in order to obtain the highest possible number of calves weaned per year. Thus, some parameters, such as the calving-first estrus interval, need to be controlled. According to Bourdon \& Brinks (1983), calving sub-season is related to calving-first estrus interval, which is related to the nutritional status of the cows and duration of the breeding season. Therefore, the duration from calving to first estrus is extremely important when assessing the reproductive performance of beef cows, as there are several factors that impact this trait. Cows that calve later with higher body condition score have lower calving-first estrus interval due to the increasing day length as summer solstice approaches (Cushman et al., 2007).

The pregnancy rates obtained in the present study may be considered high when compared to the average of $60 \%$ recorded in the state of Rio Grande do Sul (SEBRAE, SENAR \& FARSUL, 2005). This shows that the studied production system, exclusively based on natural resources, reached satisfactory reproductive indexes due to the adoption of proper management techniques. A higher number of calvings during the first sub-seasons may be achieved using strategic management techniques, such as adjustment of stocking rates, pasture resting, proper weaning season, monitoring 
body condition score of the cows, and so on. The use of these technologies allow improving production indexes through a higher number of calves born in the beginning of the calving season, as well as more uniform and heavier calf groups at weaning.

\section{Conclusions}

Multiparous cows calving in the beginning of the calving season usually present higher pregnancy rates in the following breeding season. However, the effect of subseason is more evident during years with low rainfall during the calving or breeding seasons. In this case, management practices focusing on cows that calve during the last subseasons should be introduced to reduce the effects of calving date.

\section{Acknowledgements}

To CNPq for granting research productivity sponsorship for the second author.

\section{References}

BARCELLOS, J.O.J.; SILVA, J.L.C.; SILVA M.D. et al. Desempenho de vacas e terneiros de corte submetidos ao desmame aos 60 dias. In: II CONGRESSO DE MEDICINA VETERINÁRIA DO CONE SUL, 2., BRASILEIRO DE MEDICINA VETERINÁRIA, 25., 1997, Gramado. Anais... Porto Alegre, 1997. p.256.

BARCELLOS, J.O.J. Manejo Integrado: um conceito para aumentar a produtividade dos sistemas de produção de bovinos de corte. In: LOBATO, J.F.P.; BARCELLOS, J.O.J.; KESSLER, A.M. (Orgs.). Produção de bovinos de corte. Porto Alegre, 1999. p.287-313.

BOURDON, R.M.; BRINKS, J.S. Calving date versus calving interval as reproductive meansure in beef cattle. Journal of Animal Science, v.57, n.6, p.1412-1417, 1983.
CUSHMAN, R.A.; ALAN, M.F.; THALLMAN, R.M. et al. Caracterization of biological types of cattle (Cycle VII): Influence of postpartum interval and estrus cycle length on fertility. Journal of Animal Science, v.85, n.9, p.2156-2162, 2007.

GRECELLÉ, R.A.; BARCELLOS, J.O.J.; BRACCINI, J.N. et al. Taxa de prenhez de vacas Nelore x Hereford em ambiente subtropical sob restrição alimentar. Revista Brasileira de Zootecnia, v.35, n.4, p.1423-1430, 2006.

HANSEN P.J., HAUSER E.R. Genotype $x$ environmental interactions on reproductive traits of bovine females. III. Seasonal variation in postpartum reproduction as influenced by genotype, suckling and dietary regimen. Journal of Animal Science, v.55, n.6, p.1441-1457, 1982

LOBATO, J.F.P. Gado de cria: Tópicos. Porto Alegre: Adubos Trevo, 1985. 32p.

MORRIS, S.T.; PLEASANTS, A.B.; BARTON, R.A. Post partum oestrus interval of single-suckled Angus beef cows. New Zealand Journal Agriculture Research, v.21, p.577-582, 1978

OSORO, K.; WRIGHT, I.A. The effect of body condition, live weight, breed, age, calf performance, and calving date on reproductive performance of spring-calving beef cows. Journal of Animal Science, v.70, n.6, p.1661-1666, 1992.

PIMENTEL, C.A.; PIMENTEL, M.A. Efeito do mês de parição sobre a função reprodutiva de vacas de corte. Revista Brasileira de Reprodução Animal, v.7, n.2, p.33-42, 1983.

REINHER, C.; OIAGEN, R.P.; BARCELLOS, J.O.J. et al. Histogramas de parição e o desempenho reprodutivo de vacas de corte. Acta Scienctiae Veterinariae, v.34, n.3, p.281-287, 2006.

SEBRAE, SENAR e FARSUL (Juntos para competir). Diagnóstico de sistemas de Produção de bovinocultura de corte do Estado do Rio Grande do Sul. Porto Alegre, 2005.

SILVA, A.W.L. Taxas de reconcepção e intervalo partoconcepção influenciados pela subépoca e mês de parição de vacas de corte. Porto Alegre: Universidade Federal do Rio Grande do Sul, 1989. 168f. Dissertação (Mestrado em Agronomia) - Curso de Pós-Graduação em Agronomia, Universidade Federal do Rio Grande do Sul, 1989.

STATISTICAL ANALYSES SYSTEM - SAS. SAS/STAT. User's guide. version 6. 4.ed. Cary: 1990. v.2, 1686p.

VIEIRA, A.; LOBATO, J.F.P.; TORRES, R.A.A. et al. Fatores determinantes do desempenho reprodutivo de vacas nelore na região do Brasil Central. Revista Brasileira de Zootecnia, v.34, n.6, p.2408-2416, 2005.

WILTBANK, J.N. Research needs in beef cattle reproduction. Journal of Animal Science, v.31, n.4, p.755-762, 1970. 